\title{
Reporting Period for Cancer Center Support Grant
}

National Cancer Institute

\section{Source}

National Cancer Institute. Reporting Period for Cancer Center Support Grant. NCl

Thesaurus. Code C39507.

The Reporting Period for Cancer Center Support Grant, is the 12-month period for which data are being provided for Standard Cancer Center Information Summary. 